\title{
The social cost of atmospheric release
}

\author{
Drew T. Shindell
}

Received: 23 January 2014 / Accepted: 29 January 2015 / Published online: 25 February 2015

(C) The Author(s) 2015. This article is published with open access at Springerlink.com

\begin{abstract}
I present a multi-impact economic valuation framework called the Social Cost of Atmospheric Release (SCAR) that extends the Social Cost of Carbon (SCC) used previously for carbon dioxide $\left(\mathrm{CO}_{2}\right)$ to a broader range of pollutants and impacts. Values consistently incorporate health impacts of air quality along with climate damages. The latter include damages associated with aerosol-induced hydrologic cycle changes that lead to net climate benefits when reducing cooling aerosols. Evaluating a $1 \%$ reduction in current global emissions, benefits with a high discount rate are greatest for reductions of co-emitted products of incomplete combustion (PIC), followed by sulfur dioxide $\left(\mathrm{SO}_{2}\right)$, nitrogen oxides $\left(\mathrm{NO}_{\mathrm{x}}\right)$ and then $\mathrm{CO}_{2}$, ammonia and methane. With a low discount rate, benefits are greatest for PIC, with $\mathrm{CO}_{2}$ and $\mathrm{SO}_{2}$ next, followed by $\mathrm{NO}_{\mathrm{x}}$ and methane. These results suggest that efforts to mitigate atmosphere-related environmental damages should target a broad set of emissions including $\mathrm{CO}_{2}$, methane and aerosol/ozone precursors. Illustrative calculations indicate environmental damages are \$330-970 billion $\mathrm{yr}^{-1}$ for current US electricity generation $(\sim 14-34 \varnothing$ per $\mathrm{kWh}$ for coal, $\sim 4-18 \varnothing$ for gas) and $\$ 3.80(-1.80 /+2.10)$ per gallon of gasoline $(\$ 4.80$ $(-3.10 /+3.50)$ per gallon for diesel). These results suggest that total atmosphere-related environmental damages plus generation costs are much greater for coal-fired power than other types of electricity generation, and that damages associated with gasoline vehicles substantially exceed those for electric vehicles.
\end{abstract}

\section{Introduction}

Societal assessment of environmental threats depends upon a variety of factors including physical science-based estimates of the risk of impacts and economic valuation of those impacts. Quantitative estimates of costs and benefits associated with particular policy options can inform responses, but such valuations face a myriad of issues, including the choice of which impacts to 'internalize' within the economic valuation, the value of future versus present risk, and how to compare different types of impacts on a common scale (e.g. (Arrow et al. 2013; European Commission 1995; Johnson and Hope 2012; Muller et al. 2011; National Research Council 2010, hereafter NRC2010; Nordhaus and Boyer 2000)).

Electronic supplementary material The online version of this article (doi:10.1007/s10584-015-1343-0) contains supplementary material, which is available to authorized users.

D. T. Shindell $(\bowtie)$

Nicholas School of the Environment, Duke University, PO Box 90328, Durham, NC 27708, USA

e-mail: drew.shindell@duke.edu 
To examine these issues, I explore here the economic damages associated with a marginal change in the atmospheric release of individual pollutants owing to their effects on climate and air quality. Prior studies have provided compelling demonstrations of the importance of linkages between climate change and air quality valuation (e.g. (Caplan and Silva 2005; Nemet et al. 2010; Tollefsen et al. 2009)) and of the incorporation of economics into emission metrics (e.g. (Johansson 2012; Tanaka et al. 2013)), but typically have not fully represented the climate impact of short-lived emissions, especially aerosols and methane (e.g. (International Monetary Fund 2013; Muller et al. 2011; NRC 2010)). As opposed to previous estimates of damages associated with particular activities (e.g. electricity generation (European Commission 1995)), the general values presented here allow valuation of the impact of any sector or any policy scenario whose emissions are known. While many uncertainties remain in this type of analysis, and hence caution is advised in using these values in policy decisions, this evaluation of a wide variety of pollutants nevertheless allows exploration of how society values human welfare at different timescales and in response to different environmental threats.

This work builds upon the Social Cost of Carbon (SCC), a widely used methodology for valuation of the estimated damages associated with an incremental increase in carbon dioxide $\left(\mathrm{CO}_{2}\right)$ emissions in a given year. The US Government describes it as being "intended to include (but not limited to) changes in net agricultural productivity, human health, property damages from increased flood risk, and the value of ecosystem services due to climate change." (US Government 2013; hereafter USG 2013; see also Electronic Supplementary Material (ESM)).

Thus social costs for emissions of other pollutants should at minimum include their impacts on these same quantities (health, agriculture, etc.). This applies even when their effects take place via different processes than for $\mathrm{CO}_{2}$. For example, pollutants such as black carbon (BC), organic carbon $(\mathrm{OC})$, sulfur dioxide $\left(\mathrm{SO}_{2}\right)$ or methane $\left(\mathrm{CH}_{4}\right)$, affect human health both by altering climate as $\mathrm{CO}_{2}$ does (hereafter climate-health impacts) but also by more directly degrading air quality (hereafter composition-health impacts). Hence this work assesses impacts of atmospheric pollutants regardless of the route by which they occur. It thus also builds upon prior valuation of air quality-related health impacts of emissions (e.g. (Muller et al. 2011)). Ideally, the social costs of emissions to the atmosphere should include all affected components of human welfare.

Here I evaluate a broad Social Cost of Atmospheric Release (SCAR) for emissions of the pollutants that are the major drivers of global mean climate change (Myhre et al. 2013) and of the global health burden from poor air quality (particulate matter and ozone; (Lim et al. 2012)) (Table 1). Unlike the SCC, which has nearly always been evaluated for well-mixed greenhouse gases only, the SCAR metric spans a wide range of pollutants, and thus facilitates discussion of the relative importance of those emissions with primarily a near-term influence (years to decades; aerosols, ozone precursors, methane and HFC-134a), including their compositionhealth impacts, and those with effects that are large over long-terms (centuries; long-lived greenhouse gases such as $\mathrm{CO}_{2}$ and $\mathrm{N}_{2} \mathrm{O}$ ).

\section{Methods}

\subsection{Basic climate damages}

The first component of the SCAR is climate damages that are proportional to global mean surface temperature change (equivalent to the traditional SCC). Global mean temperature changes are driven by the global mean radiative forcing (RF) caused by each emitted 
Table 1 Pollutants examined here and their major impacts

\begin{tabular}{|c|c|c|c|}
\hline & $\begin{array}{l}\text { Global mean surface } \\
\text { temperature impact }^{\mathrm{a}}\end{array}$ & $\begin{array}{l}\text { Enhanced regional } \\
\text { hydrologic cycle impact }\end{array}$ & $\begin{array}{l}\text { Pathway to composition- } \\
\text { health impacts }\end{array}$ \\
\hline Carbon dioxide $\left(\mathrm{CO}_{2}\right)$ & Warming & & None \\
\hline Methane $\left(\mathrm{CH}_{4}\right)$ & Warming & & Surface ozone \\
\hline Nitrous oxide $\left(\mathrm{N}_{2} \mathrm{O}\right)$ & Warming & & None \\
\hline HFC-134a & Warming & & None \\
\hline Black carbon $(\mathrm{BC})$ & Warming & $\mathrm{X}$ & Surface $\mathrm{PM}_{2.5}$ \\
\hline Sulfur dioxide $\left(\mathrm{SO}_{2}\right)$ & Cooling & $\mathrm{X}$ & Surface $\mathrm{PM}_{2.5}$ \\
\hline Organic carbon (OC) & Cooling & $\mathrm{X}$ & Surface $\mathrm{PM}_{2.5}$ \\
\hline Carbon monoxide (CO) & Warming & & Surface ozone \\
\hline Nitrogen oxides $\left(\mathrm{NO}_{\mathrm{x}}\right)$ & Cooling $^{\mathrm{b}}$ & $\mathrm{X}$ & Surface $\mathrm{PM}_{2.5} \&$ ozone \\
\hline Ammonia $\left(\mathrm{NH}_{3}\right)$ & Cooling & $\mathrm{X}$ & Surface $\mathrm{PM}_{2.5}$ \\
\hline Mercury $(\mathrm{Hg})^{\mathrm{c}}$ & None & & Bioaccumulation in fish \\
\hline
\end{tabular}

See ESM section 1.1 for discussion of additional pollutants that could be examined

a The global mean surface temperature impact is also a proxy for the many additional climate impacts that occur alongside global mean temperature change, including changes in sea-level, rainfall, heatwaves, etc

b The uncertainty encompasses this agent causing warming

c Valuation of the health impacts of mercury emissions has been performed for the US (see ESM section 5), and is discussed in the calculations of US sectoral impacts only

compound. RF for most emissions is based on the IPCC AR5 (Myhre et al. 2013). RF attributable to individual aerosol precursors including indirect cloud effects was not provided in AR5, and hence to incorporate this important component for $\mathrm{SO}_{2}, \mathrm{BC}$ and $\mathrm{OC}$ I use a combination of modeling and literature analysis (Shindell et al. 2012a; Shindell et al. 2009; United Nations Environment Programme and World Meteorological Organization 2011; hereafter UNEP 2011; see ESM). The relative uncertainties in RF presented in the AR5 (Myhre et al. 2013) are used for all emissions. These uncertainties, and all others used here, are assumed to be 5-95\% confidence intervals (CI).

Forcing by non- $\mathrm{CO}_{2}$ emissions includes a component driven by the response of the carboncycle to temperature changes induced by those emissions (as in the calculations for $\mathrm{CO}_{2}$ itself) based on a reduced carbon uptake of $1 \mathrm{GtC}$ per degree warming (Arora et al. 2013; Collins et al. 2013b). The uncertainty in this effect is taken to be equal to the magnitude of the effect itself (Collins et al. 2013b).

Temperature responses to forcings by each individual pollutant are calculated using the time dependence of the impulse-response function from the Hadley Centre climate model (Boucher et al. 2009). The magnitude is set to yield an equilibrium climate sensitivity (ECS) of $3.2^{\circ} \mathrm{C}$ for doubled $\mathrm{CO}_{2}$, consistent with the AR5 (Collins et al. 2013a). As valuation depends strongly on the transient climate response, uncertainty in sensitivity is based on the range in a recent study of the AR5 models $\left(1.3-3.15^{\circ} \mathrm{C}\right.$; (Shindell 2014)) relative to the mean of those models $\left(1.8^{\circ} \mathrm{C}\right.$, hence $-28 \% /+75 \%$; those models also exhibited a mean ECS of $\left.3.2{ }^{\circ} \mathrm{C}\right)$.

Basic climate damages for all pollutants in the SCAR are then calculated from their impact on global mean temperature as in the $\mathrm{SCC}$ for $\mathrm{CO}_{2}$. The $\mathrm{SCAR}$ calculations presented here use the DICE 2007 IAM damage function (Nordhaus 2008), which has damages proportional to the square of the temperature change and equal to $1.8 \%$ of world output at $2.5^{\circ} \mathrm{C}$ (see ESM for context). AR4 suggested that valuation of non-economic and economic impacts at $2.5^{\circ} \mathrm{C}$ together contributed $\sim 65 \%$ as much uncertainty to the SCC as did climate sensitivity (Yohe 
et al. 2007). Hence I set the uncertainty of the damage function to $65 \%$ of the mean uncertainty associated with climate sensitivity.

GDP increases at $2 \pm 1 \% \mathrm{yr}^{-1}$, as in SRES scenarios, giving a mean 2100 value of $\$ 355$ trillion, consistent with USG 2013. Reference temperature change follows a business-as-usual trend with projected increases of $0.015^{\circ} \mathrm{C} \mathrm{yr}^{-1}$ (as in recent observations). These gradually increase with time, then slow to $0.008{ }^{\circ} \mathrm{C} \mathrm{yr}^{-1}$ after the total increase exceeds $4{ }^{\circ} \mathrm{C}$ and the maximum tolerated warming is $4.5^{\circ} \mathrm{C}$ assuming massive societal response to large changes (similar to the 'backstop' technology deployed in DICE for large temperature changes). The modeled time horizon is 350 years, but results are minimally sensitive to variations beyond $\sim 150$ years due to the warming limit. Uncertainty in the trend is $\pm 0.005{ }^{\circ} \mathrm{C} \mathrm{yr}^{-1}$. Mean reference temperatures are $\sim 3.8{ }^{\circ} \mathrm{C}$ greater than preindustrial in 2100 , in accord with projections for the higher end emissions pathways in recent simulations (Forster et al. 2013). Values are presented for 2010 emissions in 2007 \$US (as in USG 2013).

The discount rate is an important choice in valuation of future damages. USG 2013 gives 2010 SCC values using three different constant discount rates, 5, 3 and $2.5 \%$, based on results from several IAMs examining multiple scenarios for emissions, population, GDP, etc. I use the same discount rates to facilitate comparison and as these reflect the consensus view of the US government about which values reflect plausible choices. I also include analysis using a constant discount rate of $1.4 \%$, the value used in Stern (2006). Although discount rate selection is subjective, involving growth projections, risk aversion, and ethical choices (e.g. future utility), the large wealth increase with 2-3\% annual GDP growth is less compatible with very low discount rates. Therefore, for the $1.4 \%$ discount rate case only, GDP increases at $1.3 \mathrm{yr}^{-1}$, as in Stern (2006), with an uncertainty of $+0.3 /-0.5 \% \mathrm{yr}^{-1}$. Finally, authors have argued for the use of a declining discount rate (DDR) (e.g. (Arrow et al. 2013; Gollier 2008)), and I therefore also use a rate that starts at $4 \%$ and decreases exponentially with a 250 year time constant (i.e. the percentage rate is $4 * \exp (-t / 250)$ where $t$ is the time in years) which approximates the mean behavior seen in several prior studies discussed in Arrow et al. (2013). Note that the framework employed here does not directly include any economic response to environmental damages other than the backstop assumption.

\subsection{Additional climate-health valuation}

The traditional SCC includes economic impacts of premature mortality and morbidity due to climate change, with these climate-health impacts causing $\sim 10-50 \%$ of total damages in the IAM studies summarized in Nordhaus and Boyer (2000). The DICE damage function used here includes climate-health impacts attributable to tropical diseases only (see ESM). Recent estimates of climate-health impacts by the World Health Organization (WHO) (CampbellLendrum and Woodruff 2007) find large impacts attributable to other causes, however, especially malnutrition, with 126,000 premature deaths attributed to the current warming $\left(\sim 0.8^{\circ} \mathrm{C}\right)$ via causes other than tropical diseases. I therefore perform additional climatehealth valuation calculations using this estimate, assuming these effects are also proportional to the temperature change squared. Both the magnitude and long-term trend of climate-health impacts clearly merit further study, however. As WHO provides only qualitative uncertainties, I use an uncertainty of $\pm 80 \%$, as for the composition-health impacts.

A consistent valuation methodology is used for climate-health and composition-health impact calculations. The WHO found climate-health damages, especially malnutrition, to be heavily weighted towards poorer developing nations (where carbonaceous emissions are currently large). Climate-health calculations therefore use a Value of a Statistical Life (VSL) of $\$ 1.7$ million (for 2010), which is the nominal US-based VSL of $\$ 7.5$ million adjusted to 
account for carbonaceous aerosol exposure- and population-weighted country-specific income differences from prior analyses (UNEP 2011).

Socio-economic projections affect the climate-health damages. The VSL increases along with per capita growth in GDP since it's associated with the willingness-to-pay. As in basic climate damage calculations, GDP increases at $2 \pm 1 \% \mathrm{yr}^{-1}$. Increases in population are $0.4 \% \mathrm{yr}^{-1}$, increasing the number of people exposed to health impacts while reducing per capita GDP increases. Baseline mortality decreases by $0.45 \pm 0.45 \% \mathrm{yr}^{-1}$, with the mean value matching the optimistic scenario of Mathers and Loncar (2006) and the range spanning their baseline scenario $(\sim 0 \%)$ and the more optimistic trend ( $-0.9 \%)$ in Murray and Lopez (1997).

In the WHO analysis, $46 \%$ of premature mortalities due to climate change are attributable to malnutrition. Agricultural responses to climate change are expected to be highly sensitive to $\mathrm{CO}_{2}$ fertilization effects on plants (Yohe et al. 2007). In particular, $\sim 3-10$ times more people are at risk from hunger under future scenarios (across the high SRES A1F1 and low B1) when the beneficial effects of $\mathrm{CO}_{2}$ fertilization at their maximum estimated effectiveness are excluded (Parry et al. 2004). I assume a mid-range effectiveness with 3 times more malnutrition cases for warming without $\mathrm{CO}_{2}$ fertilization, and an uncertainty of $100 \%$ so that the maximum ( 6 times more) is consistent with the central portion of the above estimate and the minimum excludes any fertilization effect. Since positive historical non- $\mathrm{CO}_{2} \mathrm{RF}$ has been largely offset by negative aerosol forcing, I assume the current WHO analysis includes $\mathrm{CO}_{2}$ fertilization. Therefore, the climate-health effects of non- $\mathrm{CO}_{2}$ emissions associated with malnutrition (46\%) are multiplied by $3 \pm 3$ to account for the $\mathrm{CO}_{2}$ fertilization effect.

\subsection{Valuation of regional precipitation changes due to aerosols}

Multiple climate modeling studies have shown that both scattering and absorbing aerosols induce strong regional hydrologic cycle changes (e.g. (Levy et al. 2013; Ramanathan and Carmichael 2008; Wang et al. 2009)), and that there is typically a substantially greater precipitation response per unit RF than for well-mixed greenhouse gases (Shindell et al. 2012a, b). As many impacts are closely related to regional changes in precipitation that directly affect water and food, attribution of damages solely to temperature may be a less accurate approximation for regionally highly uneven forcings. Therefore, I include additional impacts stemming from regional disruption of the hydrologic cycle for aerosols.

I assume all precipitation changes lead to net damages as they cause shifts relative to traditional patterns to which human systems are aligned. These shifts can also alter the intensity distribution (e.g. wet areas getting wetter and dry areas drier (Held and Soden 2006)), potentially leading to more extremes either directly (Portmann et al. 2009) or indirectly via teleconnections (Kenyon and Hegerl 2010), which would again lead to damages even in cases where changes in mean precipitation could be beneficial. Hence I assign damages to both scattering aerosols and absorbing $\mathrm{BC}$ even though the sign of their impact is sometimes opposite. It is difficult to estimate precisely what portion of the climate-related damages is due to precipitation changes. Even for a particular impact such as human health, temperature and precipitation both play important roles by influencing malnutrition, vector borne diseases, etc. (Campbell-Lendrum and Woodruff 2007). I attribute $50 \%$ of the climate-related damages to precipitation changes, and increase these by a factor of 4.2 for aerosols based on the mean ratio in prior modeling (see ESM). The portion of the global climate response attributable to carboncycle feedbacks is excluded. I assume this aerosol enhancement has an uncertainty of $\pm 50 \%$ of its mean value. 


\subsection{Composition-health valuation}

Premature deaths attributable to chronic $\mathrm{PM}_{2.5}$ (particulate matter with a diameter less than $2.5 \mu \mathrm{m}$ ) exposure are calculated using the total current outdoor $\mathrm{PM}_{2.5}$ impact on human health (3.2 million premature deaths annually (Lim et al. 2012)) and total current emissions, with the fractional contribution of each individual aerosol type given by the fractional contribution of each to population-weighted annual average surface $\mathrm{PM}_{2.5}$ calculated on a worldwide $0.5 \times$ $0.5^{\circ}$ grid (UNEP 2011; Shindell et al. 2012a). Valuation uses the current global mean population- and $\mathrm{PM}_{2.5}$ exposure-weighted VSL of $\$ 3.05$ million, calculated using the same model and methods as for the climate-health VSL (UNEP 2011) (see ESM).

Impacts of methane on human health (via ozone) are drawn from results of two global composition-climate models (Shindell et al. 2012a), whereas impacts of $\mathrm{CO}$ and $\mathrm{NO}_{\mathrm{x}}$ on health via ozone are drawn from one of those models (GISS). Impacts use population- and exposureweighted country-specific VSL for the ozone-health impact calculated for each pollutant. I account for the time-dependence of the ozone response to methane and $\mathrm{CO}$ emissions, and thus these are affected by the discount rate and projected GDP and baseline mortality, which are the same as for climate-health impacts.

The uncertainty is $\pm 80 \%$ for the composition-health impacts based on uncertainty in the epidemiological concentration-response functions and differences in the modeled concentration response to emissions changes (UNEP 2011; Anenberg et al., 2012).

\subsection{Composition-agriculture valuation}

Impacts of methane on agriculture via the induced change in surface ozone are also included. These are incorporated based upon prior work using (1) the surface ozone response to methane emissions changes from two global composition-climate models, (2) the impact of ozone on yields of four staple crops, wheat, maize, soy and rice, based on the methodology of Van Dingenen et al. (2009), and (3) their valuation using world market prices, as described in Shindell et al. (2012a).

\subsection{Uncertainty analysis}

The calculations include the specified uncertainties associated with 11 factors, as discussed throughout this section: RF, climate sensitivity, carbon-cycle response to non- $\mathrm{CO}_{2}$ forcing, damage function, regionally enhanced precipitation response to aerosols, climate-health, composition-health, baseline mortality projections, effects of $\mathrm{CO}_{2}$ fertilization on agriculture/ malnutrition, GDP projections, and reference temperature projections. I perform Monte Carlo calculations sampling each source of uncertainty randomly within its distribution. I present the median and the 5 and $95 \%$ confidence levels from a 40,000-member sample (the median is lower than the mean owing primarily to the asymmetric distributions of climate sensitivity and GDP growth in real terms). Uncertainty attributable to individual factors is presented in the ESM.

\section{Results}

Valuation of climate damages is, unsurprisingly, highly sensitive to discounting, reflecting the relative value of money over time, and estimated climate-health impacts. The median basic climate damages attributable to $\mathrm{CO}_{2}$ (equivalent to the traditional SCC) are 10-67 \$/ton in my calculations including conventional climate-health impacts from IAM estimates (Table 2). 
These values are consistent with those in many prior studies (e.g. USG 2013; NRC 2010). Median SCAR values for $\mathrm{CO}_{2}$ increase to 27-150 \$/ton adding the additional climate-health impacts, the valuation of which is larger than the total traditional SCC valuation (Table 2).

SCAR valuation for long-lived $\mathrm{N}_{2} \mathrm{O}$ is much larger than for $\mathrm{CO}_{2}$ due to its far greater radiative efficiency, but shows broadly similar sensitivity to the choice of discount rate (Table 2). In contrast, valuation for the shorter-lived pollutants is much less sensitive to discounting. This is especially true for aerosol-related species other than $\mathrm{BC}\left(\mathrm{SO}_{2}, \mathrm{OC}\right.$, $\mathrm{NO}_{\mathrm{x}}$, and $\mathrm{NH}_{3}$ ) because their composition-health impacts, which are unaffected by discounting, dominate their valuation even though the regional hydrologic cycle response makes the net climate damages of even cooling aerosols positive (see also ESM). The use of a DDR produces values between the constant 3 and $1.4 \%$ cases with the specified starting rate and decline used here (Table 2). Regardless of the discounting, the SCAR valuation per ton is much larger for methane and the five aerosol-related species than for $\mathrm{CO}_{2}$, with a ton of methane causing $\sim 30-100$ times more damage than a ton of $\mathrm{CO}_{2}$ and a ton of the aerosols

Table 2 Valuation of 2010 emissions (damages per ton in \$2007 US)

\begin{tabular}{|c|c|c|c|c|c|c|c|c|c|c|}
\hline $\begin{array}{l}\text { Valuation; discount } \\
\text { rate }\end{array}$ & $\mathrm{CO}_{2}$ & $\mathrm{CH}_{4}$ & $\mathrm{~N}_{2} \mathrm{O}$ & HFC-134a & $\mathrm{BC}$ & $\mathrm{SO}_{2}$ & $\mathrm{CO}$ & $\mathrm{OC}$ & $\mathrm{NO}_{\mathrm{x}}$ & $\mathrm{NH}_{3}$ \\
\hline Climate $^{\mathrm{a}} ; 5 \%$ & 10 & 490 & 2800 & 19,000 & 13,000 & -900 & 42 & -1800 & -56 & -240 \\
\hline Climate $^{\mathrm{a}} ; 3 \%$ & 32 & 910 & 9200 & 36,000 & 20,000 & -1400 & 90 & -2800 & -220 & -380 \\
\hline Climate $^{\mathrm{a}} ; 1.4 \%$ & 67 & 1400 & 19,000 & 56,000 & 30,000 & -2100 & 160 & -4200 & -400 & -560 \\
\hline $\begin{array}{l}\text { Regional climate, } \\
\text { aerosols; } 5 \%\end{array}$ & 0 & 0 & 0 & 0 & 19,000 & 3000 & 0 & 6100 & 90 & 820 \\
\hline $\begin{array}{c}\text { Regional climate, } \\
\text { aerosols; } 3 \%\end{array}$ & 0 & 0 & 0 & 0 & 26,000 & 4400 & 0 & 8700 & 350 & 1200 \\
\hline $\begin{array}{l}\text { Regional climate, } \\
\text { aerosols; } 1.4 \%\end{array}$ & 0 & 0 & 0 & 0 & 34,000 & 5900 & 0 & 12,000 & 600 & 1600 \\
\hline $\begin{array}{l}\text { Additional climate- } \\
\text { health }^{\text {b }} ; 5 \%\end{array}$ & 16 & 1600 & 8300 & 62,000 & 110,000 & 4500 & 140 & 9000 & 7 & 1200 \\
\hline $\begin{array}{l}\text { Additional climate- } \\
\text { health } ; 3 \%\end{array}$ & 45 & 2800 & 24,000 & 110,000 & 150,000 & 5700 & 260 & 11,000 & 30 & 1500 \\
\hline $\begin{array}{l}\text { Additional climate- } \\
\text { health }^{\mathrm{b}} ; 1.4 \%\end{array}$ & 87 & 4000 & 47,000 & 160,000 & 190,000 & 6900 & 430 & 14,000 & 50 & 1900 \\
\hline $\begin{array}{l}\text { Composition-health; } \\
5 \%\end{array}$ & 0 & 550 & 0 & 0 & 62,000 & 33,000 & 200 & 51,000 & 67,000 & 22,000 \\
\hline $\begin{array}{l}\text { Composition-health; } \\
3 \%\end{array}$ & 0 & 670 & 0 & 0 & 62,000 & 33,000 & 240 & 51,000 & 67,000 & 22,000 \\
\hline $\begin{array}{l}\text { Composition-health; } \\
1.4 \%\end{array}$ & 0 & 740 & 0 & 0 & 62,000 & 33,000 & 250 & 51,000 & 67,000 & 22,000 \\
\hline Median total; $5 \%$ & 27 & 2700 & 12,000 & 85,000 & 210,000 & 40,000 & 410 & 64,000 & 67,000 & 24,000 \\
\hline Median total; $3 \%$ & 84 & 4600 & 37,000 & 160,000 & 270,000 & 42,000 & 630 & 68,000 & 67,000 & 25,000 \\
\hline Median total; $1.4 \%$ & 150 & 6000 & 62,000 & 210,000 & 310,000 & 43,000 & 820 & 71,000 & 67,000 & 25,000 \\
\hline $\begin{array}{l}\text { Median total; declining } \\
\text { rate }\end{array}$ & 110 & 4700 & 47,000 & 160,000 & 280,000 & 42,000 & 730 & 69,000 & 67,000 & 25,000 \\
\hline
\end{tabular}

Notes: Composition-agriculture impacts via ozone are included in the sum for methane, valued at \$22, \$27 and $\$ 30$ per ton for 5, 3 and $1.4 \%$ discounting, respectively. Uncertainties are presented in Table S4

${ }^{a}$ This basic climate valuation includes IAM-based climate-health impacts

${ }^{\mathrm{b}}$ This valuation of additional climate-health impacts is based on WHO analyses as described in the section 2.2 
causing up to $\sim 7800$ times more damage. The larger valuation on a per ton basis stems primarily from the greater radiative efficiency per molecule of non- $\mathrm{CO}_{2}$ compounds relative to $\mathrm{CO}_{2}$ and the additional composition-health impacts.

Uncertainties in the valuation are often systematic across pollutants, so do not affect their relative importance. For example, the bulk of the uncertainty in damages associated with emissions of $\mathrm{SO}_{2}, \mathrm{OC}, \mathrm{NO}_{\mathrm{x}}$, and $\mathrm{NH}_{3}$ comes from the $80 \%$ range in the effect of particulate matter or ozone on human health (see ESM). Similarly, primary contributors to uncertainties in the valuation of the other emissions are climate sensitivity, climate-health impacts, and projected GDP, which are systematic across those pollutants and hence their relative importance is robust. Uncertainty in the regional aerosol impacts is obviously not systematic across all pollutants, but has minimal influence. Uncertainty in GDP, which is the most important factor for $\mathrm{CO}_{2}$ and $\mathrm{N}_{2} \mathrm{O}$, largely reflects society's willingness to pay to avoid impacts in the future (wealthier people will pay more) rather than uncertainties in the impacts themselves as for other factors. Note that attribution of uncertainty to individual factors is imperfect in a coupled, non-linear system (see ESM).

Another useful perspective can be gained by incorporating the relative magnitude of emissions of each compound as these vary enormously. I present the valuation of $1 \%$ of current global anthropogenic emissions (2010 values from Thomson et al. (2011), including open biomass burning emissions (Lamarque et al. 2010)), a level small enough that it is a marginal change (Fig. 1). With a high (5\%) discounting rate, placing a greater weight on nearterm impacts, the valuations of $1 \%$ of current emissions of products of incomplete combustion (PIC; OC, $\mathrm{BC}$ and $\mathrm{CO}$ ) that are usually co-emitted or $\mathrm{SO}_{2}$ are much larger than the valuation of any other pollutants. Carbon dioxide is valued at about $25 \%$ of the value of $\mathrm{SO}_{2}$, and $20 \%$ of the sum of PIC. Towards the other end of the discounting rate spectrum, a rate of $1.4 \%$ leads to larger impacts at long timescales, enhancing the valuation of $\mathrm{CO}_{2}$ more than five-fold and increasing the valuation of methane, $\mathrm{BC}$ and $\mathrm{CO}$ by 150 to $230 \%$ while having little impact on reflective aerosols or $\mathrm{NO}_{\mathrm{x}}$. Valuation of PIC is the largest with $1.4 \%$ discounting, followed by $\mathrm{CO}_{2}, \mathrm{SO}_{2}, \mathrm{NO}_{\mathrm{x}}$ and methane (Fig. 1). Valuation of HFC-134a is always relatively small despite it having the highest per ton valuation (see ESM) due to the small amount currently emitted. Note that open biomass burning emissions, especially those near populated areas

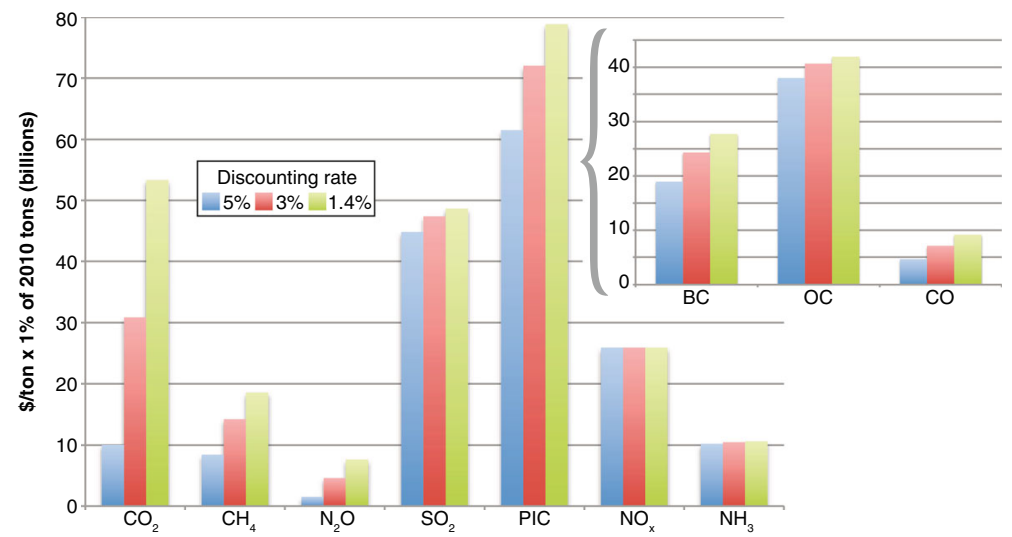

Fig. 1 SCAR valuation of $1 \%$ of current global anthropogenic (including open biomass burning) emissions to illustrate the relative benefits of a marginal change in emissions, using the indicated discount rates. Products of incomplete combustion (PIC) is the sum of BC, OC and $\mathrm{CO}$ (inset). Numerical values are in the ESM. Uncertainties are given in Table 2. Values with the declining discount rate used in this study are very similar to the $3 \%$ discounting results in this figure (see ESM) 
which have the largest effects on human health, come from fires largely started or managed by people, but are not exclusively anthropogenic.

Of course the relative ease of reducing emissions is not equivalent across pollutants or sources. The SCAR metric provides a simple way to compare the impacts of aggregate reductions once achievable values have been estimated, however. For example, the valuation of reducing products of incomplete combustion by only $\sim 2 \%$ would be comparable to that of reducing $\mathrm{CO}_{2}$ by $10 \%$ with a near-term focus (5\% discounting), while reductions would have to be $\sim 7 \%$ to be as valuable as $\mathrm{CO}_{2}$ reductions of $10 \%$ using a long-term perspective $(1.4 \%$ discounting). Similarly, reducing $\mathrm{CH}_{4}$ emissions by $\sim 12 \%$ provides as much benefit as reducing $\mathrm{CO}_{2}$ emissions by $10 \%$ with a near-term perspective, while reductions need to be $30 \%$ with a long-term view.

\section{Illustrative applications}

The SCAR can be used to explore the societal impacts of emissions attributable to particular activities and locations. For example, valuation of environmental damages due to US emissions from electricity generation, obtained by multiplying the SCAR by emissions attributed to those sectors (US EPA 2012, 2013a, b), are \$330-970 billion at $3 \%$ discounting (Table S3). Much of the uncertainty is systematic, so despite large ranges, differences can be significant (e.g. coal-related damages are $\$ 410(-180 /+240 ; 5-95 \% \mathrm{CI})$ billion greater than gas-related damages at $3 \%$ discounting). Additional damages due to the human health impacts of mercury emissions are relatively small compared to those associated with other emissions (Table S3). As the SCAR is designed to evaluate marginal emissions changes, these values for the entire sector are illustrative only, and presented primarily to facilitate comparison with prior sectoral valuation (see ESM). These calculations use the global SCAR metric, and US-specific valuations are $\sim 10-20 \%$ higher (see ESM).

Within the transportation sector, the environmental damages per unit of fuel consumption are $\$ 3.80(-1.80 /+2.10)$ per gallon of gasoline using a $3 \%$ discount rate, far larger than the current federal tax of $\$ 0.184$ per gallon and more than $7 \mathrm{x}$ greater than the typical combined local, state and federal gasoline tax (additional negative externalities associated with gasoline use should be part of an optimal fuel tax). Damages are substantially larger for diesel fuel, $\$ 4.80(-3.10 /+3.50)$ per gallon, owing to the greater BC emissions from diesel engines. USspecific valuations are $20-21 \%$ higher, so again fairly consistent with the global results.

The flexibility of the SCAR, as a general emission metric, readily allows comparison of the environmental damages associated with different fuel types or technology choices as well. I present two examples here, for power generation and vehicles. Mean US damages related to atmospheric releases for power generation are calculated on a per kWh basis by multiplying the SCAR by the emissions associated with a given fuel type (US EPA 2012, 2013a, b), then dividing by the $\mathrm{kWh}$ generated using that fuel type. Environmental damages from the US average coal-fired power plant are $24(-10 /+15) \notin$ per $\mathrm{kWh}$ with $3 \%$ discounting (median values are 19 and $30 \varnothing$ per kWh with 5 and $1.4 \%$ discounting, respectively). Comparable values for the average gas-fired plant are $8.4(-4.4 /+10.0) \notin$ per $\mathrm{kWh}(4.1$ and $12 \varnothing$ per $\mathrm{kWh})$. Total damages from coal are greater than from gas regardless of the discount rate, as the uncertainties are partially systematic and so differences are significant despite the large ranges (e.g. damages from coal are $16(-8 /+8) \notin$ per $\mathrm{kWh}$ greater than from gas for $3 \%$ discounting). There is substantial variation across coal-fired power plants, however, especially in terms of air-quality related emissions, with damages typically greater for older plants and less for newer ones. A coal plant with air-quality related emissions at the 5 th lowest percentile (about $5 \%$ of 
the average) would have damages close to those for the mean gas plant ( $\sim 8 \dot{p}$ per $\mathrm{kWh}$ for either; $3 \%$ discounting) while one at the 95th percentile (emissions about $360 \%$ of the average) would have far greater damages ( $\sim 62 \varnothing$ per $\mathrm{kWh} ; 3 \%$ discounting) based on emissions in NRC2010. Variation across gas plants is less, though still substantial, with the best combined-cycle plants having nearly twice the efficiency (and hence roughly half the damages) of typical steam or centralized turbine plants, and lower damages even than the cleanest coal-fired plants. Damages from mercury emissions are less than $1 \notin$ per kWh, so are not included here. Damages using US-specific valuation increase by $20 \%$ for coal, but by only $4 \%$ for gas as climate damages, which are independent of emission location, play a larger role in the latter.

Similarly, one can easily compute how much methane releases would have to be from the gas sub-sector (e.g. due to leakage) to produce damages as large as those from coal. Using a discount rate of $1.4 \%$, fugitive (leaked) methane emissions from natural gas systems would have to be $6.6 \%$ for the average gas-fired power plant to produce damages as large as the average coal-fired power plant on a per $\mathrm{kWh}$ basis, while with a high discount rate of $5 \%$ emissions would need to be $11 \%$. The value increases with the near-term focus inherent in the high discount rate due to the very large damages associated with $\mathrm{SO}_{2}$ and $\mathrm{NO}_{\mathrm{x}}$ emissions. In comparison with the aforementioned coal plant at the 5th percentile of current air quality emissions, the leak rate for the natural gas sector has to be only $1.9 \%, 1.6 \%$ or $1.1 \%$ for $1.4,3$ and $5 \%$ discounting, respectively, to match the damages from coal. Hence in this latter comparison, which primarily compares the effect of the $\mathrm{CO}_{2}$ and $\mathrm{CH}_{4}$ emitted by these two sectors (and hence the leak rate threshold decreases with a nearer-term perspective), even very small leak rates would make the mean natural gas plant as environmentally damaging as coal. Current estimates of methane leakage vary widely (see ESM), and hence these tradeoffs merit further consideration as better data becomes available. Note that comparison of marginal costs does not include all the factors that would be involved in a more complete transition between fuels within the energy sector.

The total levelized energy generation costs for new capacity in a recent US government estimate (Energy Information Administration 2014) are about equal for conventional coal and nuclear or renewables, with conventional combined cycle gas costing substantially less (Fig. 2). Including atmospheric environmental damages, however, coal-fired power is far more expensive than other sources, while gas becomes more expensive than nuclear or renewables (Fig. 2; contrast is slightly larger using US-specific values; Figure S5). The SCAR can also be used to assess variations between nations. For example, the environmental damages for the mean coalfired power plant in China are valued at $53(-24 /+29) \phi$ per $\mathrm{kWh}$ with $3 \%$ discounting (46 and $61 \notin$ per $\mathrm{kWh}$ with 5 and $1.4 \%$ discounting, respectively), 200-250\% more than the mean for US coal-fired power plants due to the greater levels of non- $\mathrm{CO}_{2}$ pollutants.

For vehicles, emissions from a typical midsize US gasoline powered vehicle (26 miles

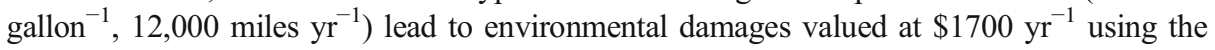
SCAR with $3 \%$ discounting. In comparison, analogous damages associated with the generation of electricity to power a midsize electric vehicle (EV; 2013 Nissan Leaf, $0.29 \mathrm{kWh}$ mile ${ }^{-1}$ (fueleconomy.gov)) are $\$ 840 \mathrm{yr}^{-1}$ for electricity from coal, $\$ 290 \mathrm{yr}^{-1}$ for electricity from natural gas and miniscule for nuclear or renewables (again the contrast is slightly larger using US-specific valuation; see ESM). Hence environmental damages are reduced substantially even if an EV is powered from coal-fired electricity, although they are much lower for other electricity sources (conclusions are similar using 5 or $1.4 \%$ discounting). Clearly, both a switch to less polluting electricity combined with vehicle electrification would be needed to reduce the majority of environmental damages associated with emissions from transportation via electrification. 


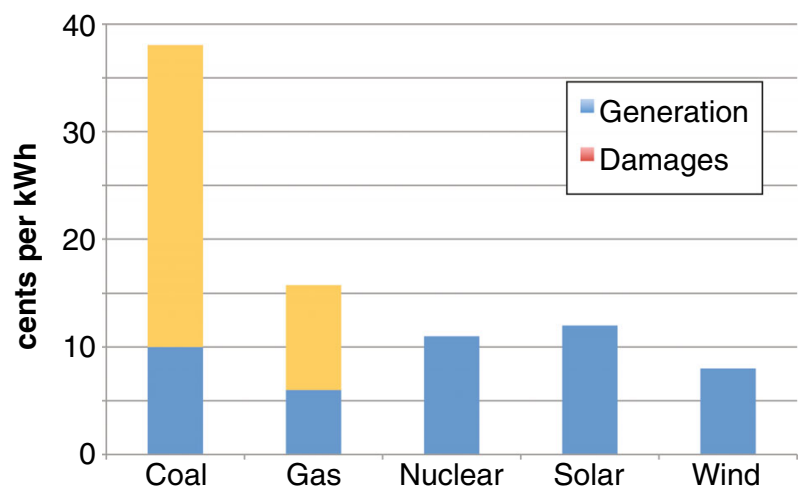

Fig. 2 Levelized generation costs for new US electricity generation and SCAR-based environmental damages by fuel type (using the global SCAR with $3 \%$ discounting). Damages are inflated to 2012 \$US to match generation costs

\section{Discussion and conclusions}

Society's will to reduce emissions is influenced by costs as well as benefits. Prior analyses have suggested the potential to achieve large reductions in emissions of all the compounds examined here at relatively low cost (Enkvist et al. 2007; Rypdal et al. 2009; Shindell et al. 2012a; UNEP 2011). Including the larger SCAR valuation would make the economics even more favorable from the perspective of a social planner considering broad societal costs. Market barriers are important, however, and the common 'split incentives' mismatch between those incurring costs and those accruing benefits can be particularly important for planet-wide benefits such as reduced climate damages (see also ESM).

Furthermore, there are multiple benefits for which valuation methodologies are not as thoroughly developed and hence which are not taken into account in this analysis. For example, neither chronic physical or mental health problems nor effects of indoor household air pollution were included (see ESM). Beyond health, additional impacts of emissions such as ocean acidification, biodiversity loss, ecosystem impacts of nitrogen deposition, and changes in visibility are omitted, suggesting that these damages are conservative and leaving ample opportunities to further improve the comprehensiveness of social cost metrics. Societal decisions will also be influenced by effects other than atmospheric release, such as impacts on fresh water, waste products (e.g. coal ash ponds, spent nuclear fuel) and national or energy security (e.g. reliance on imported fossil fuels, nuclear proliferation), which are not readily incorporated into an emission metric.

Although much further work is required to fully characterize benefits and compare with costs, this extension of SCC-type analyses to encompass a broader range of both pollutants and impacts facilitates examination of how society values various impacts occurring over different timescales. When near-term impacts are deemed most important, the results indicate that society can reap the greatest benefits by targeting emissions reductions at PIC and sulfur dioxide. This reflects the large impact of $\mathrm{PM}_{2.5}$ on near-term human health via air quality and the substantial impact of $\mathrm{BC}$ on climate. If instead longer-term impacts are given more weight, as reflected in use of a low discounting rate that arguably better captures multi-generational impacts, reductions of carbon dioxide provide comparable valuation to those of $\mathrm{PIC}$ and $\mathrm{SO}_{2}$.

The large impacts of aerosols and methane, especially at high discount rates, reflect the high immediate values placed upon reduced mortality risk by society. They appear to capture the reality that near-term health impacts seem to typically be considered more important to citizens 
than longer-term impacts of any sort, consistent with the vastly greater sums spent on medical care and research than on long-term environmental protection, and within the realm of air quality consistent with an emphasis on $\mathrm{SO}_{2}$ and $\mathrm{NO}_{\mathrm{x}}$ reductions. Such a strategy has been fairly well aligned with the optimal path suggested by this analysis given a preference for avoiding near-term impacts. However, even with such a preference, greater efforts to reduce PIC and methane emissions appear warranted due to their large impacts. To avoid longer-term damages, society clearly will have to greatly reduce $\mathrm{CO}_{2}$ emissions given their importance in total emission valuation at low discount rates. Hence these results suggest that irrespective of time preference, society should pursue a multi-pollutant emissions reduction strategy that includes multiple greenhouse gases and aerosols in order to obtain maximum socioeconomic benefits. Many potential actions, such as the examples of using renewable energy for electricity or transport, can simultaneously reduce both. Use of the SCAR metric, as in the illustrative applications presented here, can help society determine the optimal pathways to achieve such reductions.

Acknowledgments The author thanks 4 anonymous reviewers whose comments helped to substantially improve this paper, and G. Faluvegi and G. Milly for assistance with analysis of model output.

Open Access This article is distributed under the terms of the Creative Commons Attribution License which permits any use, distribution, and reproduction in any medium, provided the original author(s) and the source are credited.

\section{References}

Anenberg SC, Schwartz J, Shindell D, Amann M, Faluvegi G, Klimont Z, Janssens-Maenhout G, Pozzoli L, Van Dingenen R, Vignati E, Emberson L, Muller NZ, West JJ, Williams M, Demkine V, Hicks WK, Kuylenstierna J, Raes F, Ramanathan V (2012) Global air quality and health co-benefits of mitigating near-term climate change through methane and black carbon emission controls. Environ Health Perspect 120:831-839. doi: 10.1289/ehp.1104301

Arora VK, Boer GJ, Friedlingstein P, Eby M, Jones CD, Christian JR, Bonan G, Bopp L, Brovkin V, Cadule P, Hajima T, Ilyina T, Lindsay K, Tjiputra JF, Wu T (2013) Carbon-concentration and carbon-climate feedbacks in CMIP5 Earth system models. J Climate 26:5289-5314

Arrow K, Cropper M, Gollier C, Groom B, Heal G, Newell R, Nordhaus W, Pindyck R, Pizer W, Portney P, Sterner T, Tol RSJ, Weitzman M (2013) Determining benefits and costs for future generations. Science 341: 349-350

Boucher O, Friedlingstein P, Collins B, Shine KP (2009) The indirect global warming potential and global temperature change potential due to methane oxidation. Environ Res Lett 4. doi:10.1088/1748-9326/1084/ $1084 / 044007$

Campbell-Lendrum D, Woodruff R (2007) Climate change: quantifying the health impact at national and local levels. In: Prüss-Üstün A, Corvalán C (eds) Environmental burden of disease series, no. 14. World Health Organization

Caplan A, Silva E (2005) An efficient mechanism to control correlated externalities: redistributive transfers and the coexistence of regional and global pollution permit markets. J Environ Econ Manag 49:68-82

Collins M, Knutti R, Arblaster JM, Dufresne J-L, Fichefet T, Friedlingstein P, Gao X, Gutowski WJ, Johns T, Krinner G, Shongwe M, Tebaldi C, Weaver AJ, Wehner M (2013a) Long-term climate change: projections, commitments and irreversibility. In: Stocker TF et al (eds) Climate change 2013: The physical science basis. Contribution of working group I to the fifth assessment report of the intergovernmental panel on climate change. Cambridge University Press, Cambridge

Collins WJ, Fry MM, Yu H, Fuglestvedt JS, Shindell DT, West JJ (2013b) Global and regional temperaturechange potentials for near-term climate forcers. Atmos Chem Phys 13:2471-2485

Energy Information Administration (2014) Annual energy outlook 2014. US Dept. of Energy, Washington 
Enkvist P-A, Nauclér T, Rosander J (2007) A cost curve for greenhouse gas reduction. The McKinsey Quarterly

European Commission (1995) ExternE: externalities of energy. Office for Official Publications of the European Communities, Luxembourg

Forster PM, Andrews T, Good P, Gregory JM, Jackson LS, Zelinka M (2013) Evaluating adjusted forcing and model spread for historical and future scenarios in the CMIP5 generation of climate models. J Geophys Res Atmos 118:1139-1150

Gollier C (2008) Discounting with fat-tailed economic growth. J Risk Uncertain 37:171-186

Held IM, Soden BJ (2006) Robust responses of the hydrological cycle to global warming. J Clim 19: $5686-5699$

International Monetary Fund (2013) Energy subsidy reform: lessons and implications. International Monetary Fund, Washington

Johansson D (2012) Economics- and physical-based metrics for comparing greenhouse gases. Clim Chang 110: 123-141

Johnson LT, Hope C (2012) The social cost of carbon in U.S. regulatory impact analyses: an introduction and critique. J Environ Stud Sci. doi:10.1007/s13412-012-0087-7

Kenyon J, Hegerl G (2010) Influence of modes of climate variability on global precipitation extremes. J Clim 23: $6248-6262$

Lamarque J-F, Bond TC, Eyring V, Granier C, Heil A, Klimont Z, Lee D, Liousse C, Mieville A, Owen B, Schultz MG, Shindell D, Smith SJ, Stehfest E, Van Aardenne J, Cooper OR, Kainuma M, Mahowald N, McConnell JR, Naik V, Riahi K, van Vuuren DP (2010) Historical (1850-2000) gridded anthropogenic and biomass burning emissions of reactive gases and aerosols: methodology and application. Atmos Chem Phys 10:7017-7039

Levy H, Horowitz L, Schwarzkopf M, Ming Y, Golaz J, Naik V, Ramaswamy V (2013) The roles of aerosol direct and indirect effects in past and future climate change. J Geophys Res-Atmos 118: $4521-4532$

Lim S, Vos T, Flaxman A (2012) A comparative risk assessment of burden of disease and injury attributable to 67 risk factors and risk factor clusters in 21 regions, 1990-2010: a systematic analysis for the Global Burden of Disease Study 2010. Lancet 380:2224-2260

Mathers CD, Loncar D (2006) Projections of global mortality and burden of disease from 2002 to 2030. PLoS Med 3:e442, doi:410.1371/journal.pmed.0030442

Muller N, Mendelsohn R, Nordhaus W (2011) Environmental accounting for pollution in the United States economy. Am Econ Rev 101:1649-1675

Murray C, Lopez A (1997) Alternative projections of mortality and disability by cause 1990-2020: global burden of disease study. Lancet 349:1498-1504

Myhre G, Shindell D, Bréon F-M, Collins W, Fuglestvedt J, Huang J, Koch D, Lamarque J-F, Lee D, Mendoza B, Nakajima T, Robock A, Stephens G, Takemura T, Zhang H (2013) Anthropogenic and natural radiative forcing. In: Stocker TF et al (eds) Climate change 2013: the physical science basis. Contribution of working group I to the fifth assessment report of the intergovernmental panel on climate change. Cambridge University Press, Cambridge

National Research Council (2010) Hidden costs of energy: unpriced consequences of energy production and use. The National Academies Press, Washington

Nemet G, Holloway T, Meier P (2010) Implications of incorporating air-quality co-benefits into climate change policymaking. Environ Res Lett 5:014007

Nordhaus W (2008) A question of balance. Yale University Press, New Haven

Nordhaus W, Boyer J (2000) Warming the world: economic models of global warming. The MIT Press, Cambridge

Parry M, Rosenzweig C, Iglesias A, Livermore M, Fischer G (2004) Effects of climate change on global food production under SRES emissions and socio-economic scenarios. Glob Environ Chang Hum Policy Dimens 14:53-67

Portmann R, Solomon S, Hegerl G (2009) Spatial and seasonal patterns in climate change, temperatures, and precipitation across the United States. Proc Natl Acad Sci U S A 106:7324-7329

Ramanathan V, Carmichael G (2008) Global and regional climate changes due to black carbon. Nat Geosci 1: $221-227$

Rypdal K, Rive N, Berntsen T, Klimont Z, Mideksa T, Myhre G, Skeie R (2009) Costs and global impacts of black carbon abatement strategies. Tellus Ser B Chem Phys Meteorol 61:625-641

Shindell DT (2014) Inhomogeneous forcing and transient climate sensitivity. Nat Clim Chang 4: 274-277

Shindell DT, Faluvegi G, Koch DM, Schmidt GA, Unger N, Bauer SE (2009) Improved attribution of climate forcing to emissions. Science 326:716-718 
Shindell D, Kuylenstierna J, Vignati E, van Dingenen R, Amann M, Klimont Z, Anenberg S, Muller N, JanssensMaenhout G, Raes F, Schwartz J, Faluvegi G, Pozzoli L, Kupiainen K, Hoglund-Isaksson L, Emberson L, Streets D, Ramanathan V, Hicks K, Oanh N, Milly G, Williams M, Demkine V, Fowler D (2012a) Simultaneously mitigating near-term climate change and improving human health and food security. Science 335:183-189

Shindell DT, Voulgarakis A, Faluvegi G, Milly G (2012b) Precipitation response to regional radiative forcing. Atmos Chem Phys 12:6969-6982

Stern N (2006) Stern review on the economics of climate change. UK Treasury, London

Tanaka K, Johansson D, O’Neill B, Fuglestvedt J (2013) Emission metrics under the $2{ }^{\circ} \mathrm{C}$ climate stabilization. Clim Chang 117:933-941

Thomson A, Calvin K, Smith S, Kyle G, Volke A, Patel P, Delgado-Arias S, Bond-Lamberty B, Wise M, Clarke L, Edmonds J (2011) RCP4.5: a pathway for stabilization of radiative forcing by 2100. Clim Chang 109:77-94

Tollefsen P, Rypdal K, Torvanger A, Rive N (2009) Air pollution policies in Europe: efficiency gains from integrating climate effects with damage costs to health and crops. Environ Sci Pol 12:870-881

UNEP (2011) Near-term climate protection and clean air benefits: actions for controlling short-lived climate forcers. United Nations Environment Programme (UNEP), Nairobi

United Nations Environment Programme and World Meteorological Organization (2011) Integrated assessment of black carbon and tropospheric ozone. Nairobi

US EPA (2012) Report to congress on black carbon. Washington

US EPA (2013a) 2008 National Emissions Inventory: Review, Analysis and Highlights. US Environmental Protection Agency, Research Triangle Park, North Carolina

US EPA (2013b) Inventory of U.S. greenhouse gas emissions and sinks: 1990-2011. Washington

US Government (2013) Technical update of the social cost of carbon for regulatory impact analysis under executive order 12866. Interagency Working Group on Social Cost of Carbon

Van Dingenen R, Dentener FJ, Raes F, Krol MC, Emberson L, Cofala J (2009) The global impact of ozone on agricultural crop yields under current and future air quality legislation. Atmos Environ 43:604-618

Wang C, Kim D, Ekman AML, Barth MC, Rasch PJ (2009) Impact of anthropogenic aerosols on Indian summer monsoon. Geophys Res Lett 36:L21704. doi:10.1029/2009GL040114

Yohe GW, Lasco RD, Ahmad QK, Arnell NW, Cohen SJ, Hope C, Janetos AC, Perez RT (2007) Perspectives on climate change and sustainability. In: Parry ML, Canziani OF, Palutikof JP, van der Linden PJ, Hanson CE (eds) Climate change 2007: Impacts, adaptation and vulnerability. Contribution of working group II to the fourth assessment report of the intergovernmental panel on climate change. Cambridge University Press, Cambridge, pp 811-841 